\title{
BACILLUS SUBTILIS [EHRENBERG. (1835) COHN 1872] IMPROVES WATER USE EFFICIENCY IN MAIZE UNDER DROUGHT CONDITIONS AND TWO LIGHT INTENSITIES
}

\author{
BARRADAS, T. F. S. - SANTOS, A. C. P. - Moro, A. L. - ARAuJO, F. F.* \\ Faculty of Agricultural Sciences UNOESTE \\ Rod. Raposo Tavares km 572, 19067-175, Presidente Prudente, São Paulo, Brazil \\ *Corresponding author \\ e-mail: fabio@unoeste.br; phone: +55-183-229-3274 \\ (Received $6^{\text {th }}$ Mar 2018; accepted $21^{\text {st }}$ May 2018)
}

\begin{abstract}
The aim of this work was to evaluate the effects of Bacillus subtilis inoculation on the growth and the photosynthetic activity of maize plants under conditions of water stress in two regimes of light intensity. Plants were inoculated with two strains of $B$. subtilis directly onto the soil and maintained for 40 days in a growth chamber under controlled conditions. Two experiments were carried out under two conditions of light intensity ( 300 and $900 \mu \mathrm{mol} \mathrm{m}^{-2} \mathrm{~s}^{-1}$ photons). During the conduction of the plants, two water supply regimes based on evapotranspiration replacement were established. At 35 days of plant growth, the following physiological parameters were evaluated: photosynthetic rate, intercellular $\mathrm{CO}_{2}$ concentration, stomatal conductance, transpiration and water use efficiency. Plants were collected (40 days) to evaluate the production of dry biomass. B. subtilis increased the water use efficiency in maize plants submitted to water stress under two light intensities. The maize gas exchange response to water stress and presence of rhizobacteria were differentiated for the two light conditions. The low light intensity condition provided lower stomatal conductance and $\mathrm{CO}_{2}$ assimilation and greater efficiency in water use in plants inoculated with Bacillus subtilis (AP-3) under conditions of water deficit. The high intensity condition provided significant differences in the reduction of stomatal conductance in plants with stress compared to plants without stress when inoculated with B. subtilis PRBS-1.
\end{abstract}

Keywords: rhizobacteria, gas exchange, Zea mays, abiotic stress, seed inoculation

\section{Introduction}

The unpredictability of climate variability is one of the main sources of risk for agricultural activities (Hardaker et al., 1997). Most of the problems found in tropical crops are due to climatic causes: droughts, heavy rains and frost. For example, losses from drought reach up to $50 \%$ in some important tropical crops, such as bean, maize and soybean (Vivan et al., 2015).

Nowadays, plant growth-promoting rhizobacteria (PGPR) has been used as alternative for promoting plant resistance to environmental stresses, such as drought conditions. (Liu et al., 2013). Among the known PGPR, Bacillus subtilis [Ehrenberg. (1835) Cohn 1872] has received special attention because of its catabolic versatility and ability to colonize roots, as well as to induce the production of a large number of enzymes and metabolites that favor the growth of plants, under conditions of stresses (Mayaket al., 2004). Recently, Li et al. (2016) reported that Bacillus subtilis promoted an increase in the efficiency of water use under drought conditions by Vicia faba, and this effect was explained through the regulation of stomata during the stress period. Regarding this, Messina et al. (2015) reported that the impact of water deficit on maize yield can be mitigated by the management practices adopted and physiological characteristics of the hybrid used, reporting that the limitation of transpiration may also contribute to improving corn tolerance to drought. 
Also, it is known that B. subtilis produces phytohormones, such as auxins and gibberellins (Katz and Demain, 1977; Araujo et al., 2005) and these hormones could ameliorate the effect of stress in plants (Liu et al., 2013).

The metabolic alterations affecting plants under drought occur due to oxidative damage at the cellular level, which happens due to the unbalance between the formation of reactive oxygen species and their detoxification (Sandhya et al., 2010). There is a significant interaction between drought stress and the activity of antioxidant enzymes in plants. In this case, inoculation of rhizobacteria in plants could reduce the harmful effects by the activation of the antioxidant enzyme system (Han and Lee, 2005). Sandhya et al. (2010) found a decreased activity of the antioxidant enzymes in maize, under drought condition, inoculated with PGPR. In addition, C4 plants present high photosynthetic rate in response to optimal growth conditions. Although the factors limiting the photosynthesis have not yet been well known, Usuda et al. (1985) found that light intensity drives the increase on the production of enzymes related to photosynthesis.

When roots are sensitized by drought, they transmit chemical signals that regulate the stomatal mechanism and shoot growth (Davies and Zhang, 1991). These chemical signals are mainly composed of plant hormones, such as cytokinins, abscisic acid (ABA) and ethylene (Dodd, 2003). The production of indole-acetic acid and cytokinins induced by rhizobacteria would be an additional mechanism to attenuate the deleterious effects of water deficit in plants (Arkhipova et al., 2007). Specifically, inoculation of a cytokinin-producing strain of $B$. subtilis increased the growth of lettuce plants in water deficit soils (Arkhipova et al., 2007).

The hypothesis of this study is that $B$. subtilis could ameliorate the effect of drought on growth and photosynthesis in maize. Thus, this study evaluated the effects of $B$. subtilis inoculation on the growth and photosynthetic activity of maize under drought conditions and two regimes of light intensity.

\section{Material and methods}

\section{Bacillus subtilis}

Two strains of Bacillus subtilis (AP-3 and PRBS-2) were used in the experiments. They were isolated from soil under soybean cultivation and are characterized by Araujo et al. (2005). The strains were maintained in nutrient agar culture medium under refrigerated conditions.

\section{Study site, treatments and experimental set-up}

The study was conducted in laboratory of Unoeste, Presidente Prudente, São Paulo, Brazil. The experiments were carried out in a completely randomized arrangement, in a $3 \times 2$ factorial scheme (control and treatments with inoculation of two B. subtilis isolates in two irrigation regimes) and five replications, which totaled 30 plots. In the first experiment, plants were conducted under a light intensity regime of $900 \mu \mathrm{mol} \mathrm{m}$ $\mathrm{s}^{-1}$ and in the second experiment plants were conducted at the intensity of $300 \mu \mathrm{mol} \mathrm{m} \mathrm{m}^{-2}$ $\mathrm{s}^{-1}$. Both experiments were conducted for 40 days in a growth chamber and were maintained in the same photoperiod, temperature and humidity conditions.

The soil used in the experiments was collected from the $0-20 \mathrm{~cm}$ horizon and characterized as an acrisol (FAO, 1998), whose chemical characteristics showed the 
following values: $\mathrm{pH}\left(\mathrm{CaCl}_{2} 0.01 \mathrm{~mol} \mathrm{~L}^{-1}\right) 5.7 ; 3.9 \mathrm{mg} \mathrm{dm}^{-3}$ of $\mathrm{P}\left(\mathrm{Mehlich}^{-1}\right) ; 2.2$ mmolc $\mathrm{dm}^{-3}$ of $\mathrm{K} ; 20.3 \mathrm{mmol} \mathrm{dm}{ }^{-3}$ of $\mathrm{Ca} ; 4.3 \mathrm{mmol} \mathrm{dm}^{-3}$ of $\mathrm{Mg} ; 14.3 \mathrm{mmol} \mathrm{dm}^{-3}$ of $\mathrm{H}+\mathrm{Al}$; 151 mmole $\mathrm{dm}^{-3}$ of CEC and $65 \%$ of base saturation. Soil base saturation was increased to $80 \%$ (Raij et al., 1997) with application of dolomitic limestone. The soil was conditioned in plastic pots $(2.5 \mathrm{~kg})$, irrigated until field capacity and incubated for 60 days.

Corn seeds (Zea mays L. Hybrid SYN 7205) were inoculated with B. subtilis isolates at the time of sowing. The aqueous suspension containing each isolate at the concentration of $10^{9}$ cells per mL was applied directly onto the seeds in the planting pit in the amount of $0.1 \mathrm{~mL}$. After sowing and inoculation of the rhizobacteria, the pots were allocated into a plant growth chamber model FITOTRON® SGC 120 (Weiss Technik, UK) under temperature conditions of $28 / 18{ }^{\circ} \mathrm{C}$ day / night and cycle of $16 / 8 \mathrm{~h}$ day/night. Relative humidity was programmed to $60 \%$. Initially, soil moisture was maintained at $100 \%$ field capacity. After 15 days of plant emergence, the water stress was induced in the pots by the replacement of only $30 \%$ of the evapotranspirated water, and the control plants received $100 \%$ replacement. The daily control of evapotranspiration was carried out using the gravimetric method (Catuchi, 2011). Soil moisture contents were monitored by humidity and temperature sensors (Prochek ${ }^{\circledR}$, Decagon Devices).

\section{$\mathrm{CO}_{2}$ and $\mathrm{H}_{2} \mathrm{O}$ gas-exchange}

At 35 days of plant growth the physiological parameters related to photosynthesis were evaluated through an infrared gas analyzer (IRGA, model Li- 6400XTR, Li-Cor). Spot measurements were performed on 5 plants per treatment under photons saturating irradiance of $1,200 \mu \mathrm{mol} \mathrm{m} \mathrm{m}^{-2} \mathrm{~s}^{-1}$. The following parameters were evaluated: liquid assimilation of $\mathrm{CO}_{2}\left(\mathrm{~A}, \mathrm{mmol} \mathrm{m} \mathrm{m}^{-2}\right)$, stomatal conductance $\left(\mathrm{gs}, \mathrm{mmol} \mathrm{m} \mathrm{m}^{-2} \mathrm{~s}^{-1} \mathrm{H}_{2} \mathrm{O}\right)$, intercellular $\mathrm{CO}_{2}$ concentration $(\mathrm{Ci}, \mathrm{ppm})$ and transpiration $\left(\mathrm{E}, \mathrm{mmol} \mathrm{m} \mathrm{m}^{-2} \mathrm{~s}^{-1}\right.$ of $\left.\mathrm{H}_{2} \mathrm{O}\right)$. From these variables, the water use efficiency was calculated as $\mathrm{A} / \mathrm{E}$ (WUE, mmol mol${ }^{-1}$ ).

\section{Plant growth analysis}

The plants were harvested 40 days after sowing, separating the root system and above-ground biomass to determine dry biomass. The shoot was separated from the root $2 \mathrm{~cm}$ above the soil level and washed in water containing mild detergent to remove soil. The quantification of biomass dry weight was performed in the laboratory after drying the material on forced ventilation oven $\left(60-70{ }^{\circ} \mathrm{C}\right)$ to constant weight. The evaluation of the growth promotion was carried out by comparing the dry root and shoot masses of the inoculated plants and control, within each water replacement condition.

\section{Data analysis}

The data obtained as mean value of five replicates and significance was considered at the $95 \%$ confidence level. Normality test and ANOVA using SISVAR software (Ferreira, 2014) was performed to evaluate the effect of rhizobacteria at water stressed and non-stressed conditions and the Tukey test was used to compare the means. 


\section{Results}

ANOVA showed highly significant $(\mathrm{P} \leq 0.05)$ effects of treatments with $B$. subtilis in in most variables analyzed. It is also possible to emphasize the interactions found between aerial part and concentration of intercellular $\mathrm{CO}_{2}$ in the two light intensity (Table 1).

Table 1. ANOVA results of treatments into stress in $H$ (high) and $L$ (low) intensity with $F$ values

\begin{tabular}{c|c|c|c|c|c|c|c|c|c|c|c|c|c|c}
\hline \multirow{2}{*}{ Sources } & \multicolumn{2}{|c|}{ Shoot } & \multicolumn{2}{c|}{ Root } & \multicolumn{2}{|c|}{ A } & \multicolumn{2}{|c|}{ Ci } & \multicolumn{2}{|c|}{ gs } & \multicolumn{2}{|c|}{ E } & \multicolumn{2}{|c}{ WUE } \\
\cline { 2 - 14 } & $\mathbf{H}$ & $\mathbf{L}$ & $\mathbf{H}$ & $\mathbf{L}$ & $\mathbf{H}$ & $\mathbf{L}$ & $\mathbf{H}$ & $\mathbf{L}$ & $\mathbf{H}$ & $\mathbf{L}$ & $\mathbf{H}$ & $\mathbf{L}$ & $\mathbf{H}$ & $\mathbf{L}$ \\
\hline Treatment & $\mathrm{ns}$ & $*$ & $*$ & $*$ & $\mathrm{~ns}$ & $*$ & $*$ & $*$ & $*$ & $*$ & $\mathrm{~ns}$ & $*$ & $*$ & $*$ \\
Stress & $*$ & $*$ & $\mathrm{~ns}$ & $*$ & $\mathrm{~ns}$ & $\mathrm{~ns}$ & $\mathrm{~ns}$ & $\mathrm{~ns}$ & $\mathrm{~ns}$ & $\mathrm{~ns}$ & $\mathrm{~ns}$ & $\mathrm{~ns}$ & $*$ & $\mathrm{~ns}$ \\
T x S & $*$ & $*$ & $\mathrm{~ns}$ & $\mathrm{~ns}$ & $\mathrm{~ns}$ & $\mathrm{~ns}$ & $*$ & $*$ & $*$ & $\mathrm{~ns}$ & $\mathrm{~ns}$ & $\mathrm{~ns}$ & $*$ & $\mathrm{~ns}$ \\
\hline
\end{tabular}

$* \mathrm{P} \leq 0.05 ;$ ns: not significant

\section{Plant growth analysis}

The highest luminous intensity $\left(900 \mu \mathrm{mol} \mathrm{m} \mathrm{m}^{-2} \mathrm{~s}^{-1}\right)$ promoted a reduction on shoot growth under drought condition, but did not alter root growth. Although rhizobacteria could ameliorate the drought stress, the inoculation of both strains of B. subtilis was not able to interfere significantly with the damages caused by drought in plant growth (Table 2). For root growth, B. subtilis (PRBS-1) reduced the root biomass in the nonstressed-plants, when compared to the non-inoculated control.

Table 2. Shoot and root growth as a function of inoculation with B. subtilis in maize plants submitted to water stress under high light intensity

\begin{tabular}{|c|c|c|c|c|}
\hline \multirow{2}{*}{ Treatments } & \multicolumn{2}{|c|}{ Shoot dry mass (g plant ${ }^{-1}$ ) } & \multicolumn{2}{|c|}{ Root dry mass (g plant $\left.{ }^{-1}\right)$} \\
\hline & Without water stress & With water stress & Without water stress & With water stress \\
\hline Non-inoculated & $1.86 \pm 0.2^{\mathrm{aA}}$ & $1.48 \pm 0.2^{\mathrm{aB}}$ & $2.89 \pm 0.5^{\mathrm{a}}$ & $2.59 \pm 0.3^{\mathrm{a}}$ \\
\hline B. subtilis AP-3 & $1.99 \pm 0.3^{\mathrm{aA}}$ & $1.48 \pm 0.4^{\mathrm{aB}}$ & $2.27 \pm 0.5^{\mathrm{ab}}$ & $2.10 \pm 0.2^{\mathrm{a}}$ \\
\hline B. subtilis PRBS-1 & $2.04 \pm 0.3^{\mathrm{aA}}$ & $1.42 \pm 0.3^{\mathrm{aB}}$ & $1.86 \pm 0.3^{b}$ & $2.50 \pm 0.4^{\mathrm{a}}$ \\
\hline
\end{tabular}

Mean \pm standard error. Values followed by distinct letters, lowercase in the columns and upper case in the lines, differ by Tukey test at $5 \%$

In the second experiment under a lower luminous intensity $\left(300 \mu \mathrm{mol} \mathrm{m} \mathrm{m}^{-2} \mathrm{~s}^{-1}\right)$, maize plants showed different responses regarding the presence of rhizobacteria than those found under the greater luminous intensity. It was found that plant inoculation with the B. subtilis (PRBS-1) resulted in increased shoot and root biomass production under drought condition (Table 3).

\section{$\mathrm{CO}_{2}$ and $\mathrm{H}_{2} \mathrm{O}$ gas-exchange}

Under high light intensity, maize did not show significant changes in photosynthetic parameters in non-inoculated plants under drought condition, but there was an increase in water use efficiency. Inoculation of maize with B. subtilis (PRBS-1) promoted a reduction in the rate of $\mathrm{CO}_{2}$ assimilation and stomatal conductance when the plants 
underwent drought condition as compared to the non-stressed plants (Table 4). Under drought condition, plants inoculated with B. subtilis (AP-3) showed a significant reduction in intercellular $\mathrm{CO}_{2}$ concentration. On the other hand, under normal condition, B. subtilis (AP-3) provided the highest rates of intercellular $\mathrm{CO}_{2}$ than non-inoculated plants.

Maize plants inoculated with $B$. subtilis (AP-3) showed higher water use efficiency compared to non-inoculated plants, both under normal and drought condition (Table 5). However, the plant-water saving observed in the inoculated plants was not reflected in the improvement or maintenance of the physiological variables related to photosynthesis. It suggests that, under high luminous intensity, the economy of water may have been resulting of other effects promoted by the presence of PGPR.

Table 3. Shoot and root growth as a function of inoculation with B. subtilis in maize plants submitted to water stress under low light intensity

\begin{tabular}{|c|c|c|c|c|}
\hline \multirow{2}{*}{ Treatments } & \multicolumn{2}{|c|}{ Shoot dry mass $\left(\mathrm{g} \mathrm{plant}^{-1}\right)$} & \multicolumn{2}{|c|}{ Root dry mass (g plant $\left.{ }^{-1}\right)$} \\
\hline & Without water stress & With water stress & Without water stress & With water stress \\
\hline Non-inoculated & $2.21 \pm 0.09^{\mathrm{bA}}$ & $0.59 \pm 0.09^{\mathrm{bB}}$ & $0.93 \pm 0.18^{\mathrm{aA}}$ & $0.40 \pm 0.08^{\mathrm{bB}}$ \\
\hline B. subtilis AP-3 & $2.14 \pm 0.08^{\mathrm{bA}}$ & $0.70 \pm 0.06^{\mathrm{bB}}$ & $0.90 \pm 0.2^{\mathrm{aA}}$ & $0.47 \pm 0.1^{\mathrm{bB}}$ \\
\hline B. subtilis PRBS-1 & $2.37 \pm 0.06^{\mathrm{aA}}$ & $1.71 \pm 0.15^{\mathrm{aB}}$ & $0.98 \pm 0.25^{\mathrm{aA}}$ & $0.80 \pm 0.15^{\mathrm{aA}}$ \\
\hline
\end{tabular}

Mean \pm standard error. Values followed by distinct letters, lowercase in the columns and upper case in the lines, differ by Tukey test at $5 \%$

Table 4. Net assimilation of $\mathrm{CO}_{2}(A)$, intercellular $\mathrm{CO}_{2}$ concentration (Ci) and stomatal conductance $\left(g_{s}\right)$, as a function of inoculation with $B$. subtilis in maize plants subjected to water stress under high light intensity

\begin{tabular}{|c|c|c|c|c|c|c|}
\hline \multirow{2}{*}{ Treatments } & \multicolumn{2}{|c|}{$\begin{array}{c}\mathrm{A} \\
\left(\mu \mathrm{mol} \mathrm{CO} \mathrm{C}_{2} \mathrm{~m}^{-2} \mathrm{~s}^{-1}\right)\end{array}$} & \multicolumn{2}{|c|}{$\begin{array}{c}\mathbf{C i} \\
(\mathbf{p p m})\end{array}$} & \multicolumn{2}{|c|}{$\stackrel{\mathrm{g}_{\mathrm{s}}}{\left(\mathrm{mmol} \mathrm{H}_{2} \mathrm{O} \mathrm{m}^{-2} \mathrm{~s}^{-1}\right)}$} \\
\hline & $\begin{array}{c}\text { Without } \\
\text { water stress }\end{array}$ & $\begin{array}{c}\text { With water } \\
\text { stress }\end{array}$ & \begin{tabular}{c|} 
Without \\
water stress
\end{tabular} & $\begin{array}{l}\text { With water } \\
\text { stress }\end{array}$ & $\begin{array}{c}\text { Without } \\
\text { water stress }\end{array}$ & $\begin{array}{c}\text { With water } \\
\text { stress }\end{array}$ \\
\hline Non-inoculated & $11.7 \pm 1.8$ & $13.1 \pm 1.7$ & $207 \pm 22^{\mathrm{bA}}$ & $188 \pm 19^{\mathrm{aA}}$ & $82 \pm 8.9^{\mathrm{aA}}$ & $91 \pm 11^{\mathrm{aA}}$ \\
\hline B. subtilis AP-3 & $11.4 \pm 1.9$ & $13.8 \pm 2.0$ & $276 \pm 28^{\mathrm{aA}}$ & $214 \pm 25^{a B}$ & $95 \pm 7.3^{\mathrm{aA}}$ & $85 \pm 9.0^{\mathrm{aA}}$ \\
\hline B. subtilis PRBS-1 & $15.0 \pm 2.3$ & $10.6 \pm 1.8$ & $225 \pm 27^{\mathrm{abA}}$ & $238 \pm 29^{\text {aA }}$ & $103 \pm 12^{\mathrm{aA}}$ & $70 \pm 8.5^{\mathrm{aB}}$ \\
\hline
\end{tabular}

Mean \pm standard error. Values followed by distinct letters, lowercase in the columns and upper case in the lines, differ by Tukey test at 5\%

Table 5. Transpiration rate (E) and water use efficiency (WUE) as a function of inoculation with B. subtilis in maize plants submitted to water stress under high light intensity

\begin{tabular}{|c|c|c|c|c|}
\hline \multirow{2}{*}{ Treatments } & \multicolumn{2}{|c|}{$\begin{array}{c}\mathrm{E} \\
\left(\mathrm{mmol} \mathrm{H}_{2} \mathrm{O} \mathrm{m}^{-2} \mathrm{~s}^{-1}\right)\end{array}$} & \multicolumn{2}{|c|}{$\begin{array}{c}\text { WUE } \\
\left(\mathrm{mol} \mathrm{CO}_{2} \mathrm{~mol} \mathrm{H}_{2} \mathrm{O}^{-1}\right)\end{array}$} \\
\hline & Without water stress & With water stress & Without water stress & With water stress \\
\hline Non-inoculated & $2.0 \pm 0.3$ & $2.2 \pm 0.5$ & $4.5 \pm 0.5^{\mathrm{cB}}$ & $5.9 \pm 0.3^{\mathrm{bA}}$ \\
\hline B. subtilis AP-3 & $2.1 \pm 0.4$ & $2.0 \pm 0.6$ & $5.5 \pm 0.4^{\mathrm{bB}}$ & $6.6 \pm 0.3^{\mathrm{aA}}$ \\
\hline B. subtilis PRBS-1 & $2.3 \pm 0.3$ & $1.8 \pm 0.4$ & $6.4 \pm 0.4^{\mathrm{aA}}$ & $5.6 \pm 0.2^{\mathrm{bA}}$ \\
\hline
\end{tabular}

Mean \pm standard error. Values followed by distinct letters, lowercase in the columns and upper case in the lines, differ by Tukey test at $5 \%$ 
With lower luminous intensity $\left(300 \mu \mathrm{mol} \mathrm{m} \mathrm{m}^{-2} \mathrm{~s}^{-1}\right)$ the assimilation and intercellular concentration of $\mathrm{CO}_{2}$ were reduced in the non-inoculated plants under drought condition. In the absence of drought, plants inoculated with B. subtilis (PRBS-1) showed a lower photosynthetic rate as compared to the non-inoculated plants; this condition could be explained by the decrease in stomatal conductance (Table 6). However, under drought condition, inoculation of plants with both B. subtilis (AP-3 and PRBS-1) did not result in photosynthesis alteration; although plants inoculated with the B. subtilis (PRBS-1) have shown higher intercellular $\mathrm{CO}_{2}$ concentration and lesser stomatal conductance.

Inoculation with $B$. subtilis promoted a lesser transpiration in plants under drought condition. It means that inoculated plants presented lower water losses, as a direct consequence of the stomatal conductance reduction. However, this reduction of stomatal conductance in inoculated plants was not sufficient to decrease the photosynthetic activity. This fact may have contributed to the improvement of the inoculated plants' performance in terms of water use efficiency (Table 7), both under normal and drought conditions.

Table 6. Net assimilation of $\mathrm{CO}_{2}(A)$, intercellular $\mathrm{CO}_{2}$ concentration $(\mathrm{Ci})$ and stomatal conductance $\left(g_{s}\right)$, as a function of inoculation with B. subtilis in maize plants subjected to water stress under low light intensity

\begin{tabular}{|c|c|c|c|c|c|c|}
\hline \multirow{2}{*}{ Treatments } & \multicolumn{2}{|c|}{$\begin{array}{c}\mathrm{A} \\
(\mu \mathrm{mol} \mathrm{CO} \\
\left.\mathrm{CO}^{-2} \mathrm{~s}^{-1}\right)\end{array}$} & \multicolumn{2}{|c|}{$\begin{array}{c}\mathbf{C i} \\
(\mathbf{p p m})\end{array}$} & \multicolumn{2}{|c|}{$\stackrel{\mathrm{g}_{\mathrm{s}}}{\left(\mathrm{mmol} \mathbf{H}_{2} \mathbf{O} \mathrm{m}^{-1} \mathrm{~s}^{-1}\right)}$} \\
\hline & $\begin{array}{c}\text { Without } \\
\text { water stress }\end{array}$ & $\begin{array}{c}\text { With water } \\
\text { stress }\end{array}$ & \begin{tabular}{|c|} 
Without \\
water stress \\
\end{tabular} & \begin{tabular}{|c|} 
With water \\
stress \\
\end{tabular} & \begin{tabular}{|c|} 
Without \\
water stress
\end{tabular} & $\begin{array}{c}\text { With water } \\
\text { stress }\end{array}$ \\
\hline Non- inoculated & $4.91 \pm 0.4^{\mathrm{a}}$ & $4.05 \pm 0.3^{\mathrm{a}}$ & $308 \pm 54^{\mathrm{aA}}$ & $171 \pm 35^{\mathrm{bB}}$ & $39 \pm 2.6^{\mathrm{a}}$ & $36 \pm 2.1^{\mathrm{a}}$ \\
\hline B. subtilis AP-3 & $4.00 \pm 0.3^{\mathrm{ab}}$ & $3.76 \pm 0.4^{\mathrm{a}}$ & $284 \pm 32^{\mathrm{aA}}$ & $216 \pm 48^{\mathrm{abA}}$ & $30 \pm 2.1^{b}$ & $28 \pm 3.0^{b}$ \\
\hline B. subtilis PRBS-1 & $3.15 \pm 0.3^{b}$ & $3.52 \pm 0.2^{\mathrm{a}}$ & $238 \pm 42^{\mathrm{aA}}$ & $258 \pm 42^{\mathrm{aA}}$ & $26 \pm 1.9^{b}$ & $25 \pm 1.7^{b}$ \\
\hline
\end{tabular}

Mean \pm standard error. Values followed by distinct letters, lowercase in the columns and upper case in the lines, differ by Tukey test at $5 \%$

Table 7. Transpiration rate (E) and water use efficiency (WUE) as a function of inoculation with B. subtilis in maize plants submitted to water stress under low light intensity

\begin{tabular}{|c|c|c|c|c|}
\hline \multirow{2}{*}{ Treatments } & \multicolumn{2}{|c|}{$\begin{array}{c}\mathrm{E} \\
\left(\mathrm{mmol} \mathrm{H}_{2} \mathrm{O} \mathrm{m}^{-2} \mathrm{~s}^{-1}\right)\end{array}$} & \multicolumn{2}{|c|}{$\begin{array}{c}\text { WUE } \\
\left(\mathrm{mol} \mathrm{CO}_{2} \mathrm{~mol} \mathrm{H}_{2} \mathrm{O}^{-1}\right)\end{array}$} \\
\hline & $\begin{array}{c}\text { Without water } \\
\text { stress }\end{array}$ & $\begin{array}{c}\text { With water } \\
\text { stress }\end{array}$ & $\begin{array}{c}\text { Without water } \\
\text { stress }\end{array}$ & $\begin{array}{c}\text { With water } \\
\text { stress }\end{array}$ \\
\hline Non-inoculated & $0.40 \pm 0.09^{\mathrm{a}}$ & $0.47 \pm 0.11^{\mathrm{a}}$ & $8.2 \pm 1.1^{\mathrm{b}}$ & $10.1 \pm 0.9^{c}$ \\
\hline B. subtilis AP-3 & $0.36 \pm 0.08^{a b}$ & $0.30 \pm 0.05^{b}$ & $13.9 \pm 1.9^{\mathrm{a}}$ & $12.6 \pm 1.2^{\mathrm{a}}$ \\
\hline B. subtilis PRBS-1 & $0.25 \pm 0.05^{\mathrm{b}}$ & $0.29 \pm 0.06^{b}$ & $10.7 \pm 1.3^{\mathrm{a}}$ & $12.3 \pm 1.1^{\mathrm{b}}$ \\
\hline
\end{tabular}

Mean \pm standard error. Values followed by distinct letters differ by Tukey test at $5 \%$

Comparing the behavior of the plants inoculated with B. subtilis (AP3) in relation to the non-inoculated plants, it was observed that in the condition of low light intensity there were larger changes in the photosynthetic parameters of the inoculated plants (Fig. 1). 


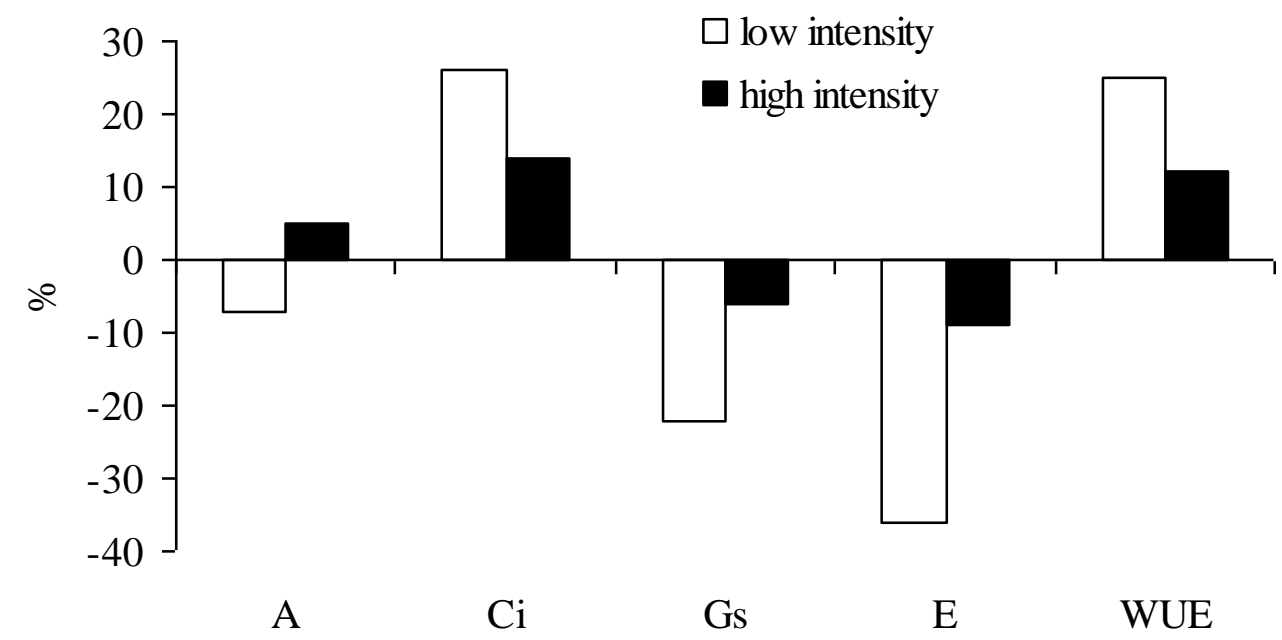

Figure 1. Percentage variations found in photosynthetic parameters in corn $(A=$ transpiration; $\mathrm{Ci}=$ intercellular $\mathrm{CO}_{2}$ concentration; $\mathrm{Gs}=$ stomatal conductance; $\mathrm{E}=$ Net assimilation of $\mathrm{CO}_{2}$ and $W U E=$ water use efficiency) In the comparison of plants in the treatment with $B$. subtilis

$(A P-3)$ with those of the control treatment under water stress and two light intensities: low $\left(300 \mu \mathrm{mol} \mathrm{m} \mathrm{m}^{-2}\right)$; high $\left(900 \mu \mathrm{mol} \mathrm{m} \mathrm{s}^{-1}\right)$

\section{Discussion}

Net $\mathrm{CO}_{2}$ assimilation rate (A) increased with the increase of light intensity but did not correlate with increased conversion of $\mathrm{CO}_{2}$ to carbohydrates (Sun et al., 2012). In our study it was verified that the plants under high luminous intensity assimilated more than twice $\mathrm{CO}_{2}$ and presented greater stomatal conductance compared to the plants under low light intensity. However, the concentration of intercellular $\mathrm{CO}_{2}(\mathrm{Ci})$ was similar in both conditions. One of the primary effects of drought condition in plants is related to the partial or total closure of the stomata (Lopes and Lima, 2015). However, other studies have shown that photosynthesis is not only regulated by the $\mathrm{CO}_{2}$ diffusion through stomata, and that other non-stomatal factors can affect photosynthetic activity in response to stressful environments (Becker and Fock, 1986; Yuet et al., 2009). Becker and Fock (1986) reported the reduction of $\mathrm{CO}_{2}$ assimilation, but did not observe changes in intercellular $\mathrm{CO}_{2}(\mathrm{Ci})$, in plants under drought condition. However, these authors found a marked reduction in the activity of important enzymes in the photosynthetic process.

Confirming hypothesis, the results found in our study suggest that B. subtilis can ameliorate the deleterious effects of drought stress, by interfering with the gas flow related to photosynthesis, and water status of the plants. However, this activity was affected by light intensity, because in the low light intensity there were significant changes in few parameters evaluated, including plant growth. Based on the interactions found by ANOVA (Table 1), it was observed that the high light intensity condition provided stress interactions with the treatments in the stomatal conductance and water use efficiency parameters, which was absent in the low light intensity condition.

Li et al. (2016) concluded that leaf application of B. subtilis in beans (Phaseolus vulgaris) improved the efficiency of water use, mainly by the closure of the stomata. These same authors also reported that the restriction of photosynthesis can be attributed to the reduction of the atmospheric $\mathrm{CO}_{2}$ input caused by the stomatal limitation induced by the presence of the rhizobacteria. B. subtilis (PRBS-1) inoculation in maize resulted 
in lower stomatal conductance when plants were subjected to water stress conditions. The partial reduction of stomatal conductance proportionally limits transpiration more than $\mathrm{CO}_{2}$ entry into leaves (Chaves and Oliveira, 2004). Our results corroborate this findings, since in the condition of lower luminous intensity, the effects of rhizobacteria inoculation occurred by the reduction of transpiration under drought condition. However, the reduction of transpiration was not followed by a reduction in photosynthesis, which resulted in higher water use efficiency (WUE). The observed increase in intercellular $\mathrm{CO}_{2}$ concentration as an effect of the PRBS-1 isolate under water stress conditions explain the absence of reduction in the photosynthetic activity of the inoculated plants. Previous studies also indicated that the accumulation of intercellular $\mathrm{CO}_{2}$ acts as a defense mechanism against water deficit, since carbon and water retention in foliar tissue are observed with the increase of the WUE (Blum, 2005; Tardieu, 2012).

Liu et al. (2013) concluded that the increase in the growth of Platycladus orientalis plants when inoculated with $B$. subtilis under drought conditions, results from the effect of increased cytokinin concentration in the leaves. It is also noteworthy that the $B$. subtilis isolates used in this study have already been characterized as phytohormone producers (Araujo et al., 2005). However, it is well known that when plants are stimulated to close the stomata in stressful situations, there may be an improvement in their efficiency in the use of water (Davies et al., 2002). Our results showed higher values of water use efficiency in $B$. subtilis inoculated plants, besides increased plant growth when plants were submitted to water stress in lower light intensity conditions, when compared to non-inoculated plants. However, the interaction with water stress only occurred with the condition of high luminous intensity.

In the analysis of the parameters related to the gas exchange, for both water regimes it was verified that in the condition of lower light intensity, the plants were more responsive to the rhizobacteria inoculation, mainly in the condition of water stress. In Figure 1 it can be verified that the isolate AP-3 of B. subtilis provided better photosynthetic performances in the plant when it was cultivated in the condition of lower luminosity. Under a lower luminous intensity, there was a reduction in stomatal conductance and consequently lower water loss due to transpiration as the effects of $B$. subtilis plant inoculation. The reduction of transpiration in plants inoculated by rhizobacteria has been reported by Bresson et al. (2013) as a mechanism supporting plant tolerance to drought. Messina et al. (2015) concluded that maize hybrids with limited transpiration characteristics would be more suitable for cultivation in regions with a higher prevalence of dry periods. In this respect, it was observed that B. subtilis (PRBS-1) reduced the transpiration of maize plants even in the absence of water deficit, and on the other hand, promoted a significant increase of plant dry mass (Table 6). However, when the plants were conducted under higher luminous intensity, the transpiration was not influenced by water stress or rhizobacteria inoculation.

Few studies compare the photosynthetic activity of corn in different conditions of light flux, under water stress. It is known that $\mathrm{C} 4$ plants have great potential for acclimatization to environmental changes and that too much light absorption can cause serious problems, which is why special mechanisms protect the photosynthetic system from excessive light (xanthophyll cycle). The multiple levels of photosynthesis control enable plants to successfully grow in a changing environment with different habitats (Taiz and Zeiger, 2004). In a study with maize growth in two light conditions under direct sunlight $\left(2000 \mu \mathrm{mol} \mathrm{m} \mathrm{m}^{-2}\right)$ and in the growth chamber $\left(400 \mu \mathrm{mol} \mathrm{m} \mathrm{m}^{-2}\right)$, plants 
grew 2.3 times more at the lowest luminous density (Usuda et al., 1985). In our study, the plants in conditions of low light density had lower photosynthetic rates and also had decreased shoot growth. Mojses and Kalapos (2008) in a study with luminous intensity variation in invasive and non-invasive $\mathrm{C} 4$ plants verified differences and the adaptation potential of these plants to semiarid conditions, represented by the lower luminous intensity, where there was a greater reduction of gas exchange by stomata and an increase in water use efficiency. The condition of lower light intensity in corn and inoculation of $B$. subtilis (AP-3) also resulted in greater closure of the stomata and increase in water use efficiency, comparing the non-inoculated plants (Fig. 1). In this sense, maize cultivation in tropical regions, at times of the year with less light radiation, such as winter, can provide better responses to inoculation of rhizobacteria in order to mitigate the effects of drought.

Several studies have already presented the potential of the B. subtilis rhizobacterium as a plant growth promoter, highlighting the production of antibiotics in the control of pathogens (Araujo et al., 2005); production of growth regulators (Molla et al., 2001) and nutrient solubilization (Kim et al., 1998), among others. In addition to these benefits previously presented in other studies, we can indicate that this species demonstrates potential to reduce the damages caused by water stress in agricultural crops, confirming what has already been reported by Li et al. (2016), who concluded that B. subtilis acts as a regulator of photosynthesis and promotes improvements in the efficiency of water use. However, light intensity can influence this regulation by factors not evaluated in this study. In this sense, our findings on the effects of the inoculation of B. subtilis on maize growth, in water deficit conditions, may foster new studies about this mechanism of action with a focus on field experiments.

\section{Conclusion}

In conclusion, the inoculation of $B$. subtilis increased the water use efficiency in maize plants subjected to water stress, under two light intensities. The maize gas exchange response to water stress and presence of rhizobacteria were differentiated for the two light conditions. The low light intensity condition provided lower stomatal conductance and greater efficiency in water use, in plants inoculated with Bacillus subtilis AP-3 under conditions of water deficit. The high intensity condition provided significant differences in the reduction of stomatal conductance in plants with stress compared to plants without stress when inoculated with B. subtilis PRBS-1.

Acknowledgements. This project was financed by Fundação de Amparo a Pesquisa do estado de São Paulo - FAPESP (Proc. 2013/20328-0).

\section{REFERENCES}

[1] Araujo, F. F., Hennig, A. A., Hungria, M. (2005): Phytohormones and antibiotics produced by Bacillus subtilis and their effects on seed pathogenic fungi and on soybean root development. - World Journal of Microbiology \& Biotechnology 21: 1639-1645.

[2] Arkhipova, T. N., Prinsen, E., Veselov, S. U., Martinenko, E. V., Melentiev, A. I., Kudoyarova, G. R. (2007): Cytokinin producing bacteria enhance plant growth in drying soil. - Plant Soil 292: 305-315. 
[3] Becker, T. W., Fock, H. P. (1986): Effects of water stress on the gas exchange, the activities of some enzymes of carbon and nitrogen metabolism, and on the pool sizes of some organic acids in maize leaves. - Photosynthesis Research 8: 175-181.

[4] Blum, U. (2005): Relationships between phenolic acid concentrations, transpiration, water utilization, leaf area expansion, and uptake of phenolic acids: nutrient culture studies. - Journal of Chemical Ecology 31: 1907-1932.

[5] Bresson, J., Varoquaux, F., Bontpart, T., Touraine, B., Vile, D. (2013): The PGPR strain Phyllobacterium brassicacearum STM196 induces a reproductive delay and physiological changes that result in improved drought tolerance in Arabidopsis. - New Phytol 200: 558-69.

[6] Catuchi, T. A., Vitolo, H. F., Bertolli, S. C., Souza, G. M. (2011): Tolerance to water deficiency between two soybean cultivars: transgenic versus conventional. - Ciência Rural 31: 373-378.

[7] Chaves, M. M., Oliveira, M. M. (2004): Mechanisms underlying plant resilience to water deficits: prospects for water-saving agriculture. - Journal of Experimental Botany 55: 2365-2384.

[8] Davies, W. J., Zhang, J. (1991): Root signals and the development of plants growing in drying soil. - Ann Rev Plant Physiol Molec Biol 42: 55-76.

[9] Davies, W. J., Wilkinson, S., Loveyes, B. (2002): Stomatal control by chemical signaling and the exploitation of this mechanism to increase water use efficiency in agriculture. New Phytol 153: 449-460.

[10] Dodd, I. C. (2003): Hormonal interactions and stomatal responses. - J. Plant Growth Regul 22: 32-46.

[11] FAO (1998): World reference base for soil resources. - International Society of Soil Science, Rome.

[12] Ferreira, D. F. (2014): Sisvar: a guide for its bootstrap procedures in multiple comparisons. - Ciênc. Agrotecnol. 38: 109-112.

[13] Han, H. S., Lee, K. D. (2005): Plant growth promoting rhizobacteria effect on antioxidant status, photosynthesis, mineral uptake and growth of lettuce under soil salinity. - J. Agri Biolo Sci 1: 210-215.

[14] Hardaker, J. B., Huirne, R. B. M., Anderson, J. R. (1997): Coping with Risk in Agriculture. - CAB International, Wallingford.

[15] Katz, E., Demain, A. L. (1977): The peptide antibiotics of Bacillus: Chemistry, biogenesis and possible functions. - Bacteriological Reviews 41: 449-474.

[16] Kim, K. Y., Jordan, D., McDonald, G. A. (1998): Enterobacter agglomerans, phosphate solubilizing bacteria, and microbial activity in soil: effect of carbon sources. - Soil Biol Biochem 30: 995-1003.

[17] Li, Y., Xu, S., Gao, J., Pan, S., Wang, X. G. (2016): Bacillus subtilis-regulation of stomatal movement and instataneous water use efficiency in Vicia faba. - Plant Growth Regul 78: 43-45.

[18] Liu, F. Xing, S., Ma, H., Du, Z., Ma, B. (2013): Cytokinin-producing, plant growthpromoting rhizobacteria that confer resistance to drought stress in Platycladus orientalis container seedlings. - Appl Microbiol Biotechnol 97: 9155-9164.

[19] Lopes, N. F., Lima, M. G. S. (2004): Fisiologia da produção. 1. ed. - UFV, Viçosa.

[20] Mayak, S., Tirosh, T., Glick, B. R. (2004): Plant growth-promoting bacteria confer resistance in tomato plants to salt stress. - Plant Physiol Biochem 42: 565-72.

[21] Messina, C. D., Sinclair, T. R., Hammer, G. L., Curan, D., Thompson, J., Oler, Z., Gho, C, Cooper, M. (2015): Limited-transpiration trait may increase maize drought tolerance in the US Corn Belt. - Agron J 107: 1978-1986.

[22] Mojzes, A., Kalapos, T. (2008): Leaf gas exchange responses to abrupt changes in light intensity for two invasive and two non-invasive $\mathrm{C} 4$ grass species - Environmental and Experimental Botany 64: 232-238. 
[23] Molla, A. H., Shamsuddinb, Z. H., Halimib, M. S., Morziahc, M., Puteh, A. B. (2001): Potential for enhancement of root growth and nodulation of soybean co-inoculated with Azospirillum and Bradyrhizobium in laboratory systems. - Soil Biology and Biochemistry 33: 457-463.

[24] Raij, B. V., Cantarella, H., Quaggio, J. A., Furlani, A. M. C. (1997): Recomendações de adubação e calagem para o Estado de São Paulo. 2.ed. - Instituto Agronômico/Fundação IAC, Campinas (Boletim Técnico, 100).

[25] Sandhya, V., Ali, S. Z., Grover, M. R., Gopal, V. B. (2010): Effect of plant growth promoting Pseudomonas spp on compatible solutes, antioxidant status and plant growth of maize under drought stress. - Plant Growth Regul 62: 21-30.

[26] Sun, W, Ubierna, N., Ma, J. Y., Cousins, A. B. (2012): The influence of light quality on $\mathrm{C}_{4}$ photosynthesis under steady-state conditions in Zea mays and Miscanthus $\times$ giganteus: changes in rates of photosynthesis but not the efficiency of the $\mathrm{CO}_{2}$ concentrating mechanism. - Plant Cell Environ 35: 982-993.

[27] Taiz, L., Zeiger, E. (2004): Fisiologia vegetal. - Artmed, Porto Alegre.

[28] Tardieu, F. (2012): Any trait or trait-related allele can confer drought tolerance: just design the right drought scenario. - J Exp Bot 63: 25-31.

[29] Usuda, H., Ku, M. S. B., Edwards, G. E. (1985): Influence of intensity during growth on photo synthesis and activity of several key photosynthetic enzymes in a C4 plant (Zea Mays). - Physiol Plant 63: 65-70.

[30] Vivan, G. A., Robaina, A. D., Peiter, M. X., Parizi, A. R. C., Barboza, F. S., Soares, F. C. (2015): Rendimento e rentabilidade das culturas da soja, milho e feijão cultivados sob condições de sequeiro. - Ciências Agrárias, Semina 36: 2943-2950.

[31] Yu, D. et al. (2009): Stomatal and no-stomatal limitations to photosynthesis in fieldgrown grapevine cultivars. - Biol. Plantarum 53: 133: 137. 